\title{
PENGARUH KUALITAS PRODUK TERHADAP KEPUASAN KONSUMEN MENGGUNAKAN PRODUK TUPPERWARE DI KOTA PALU
}

\author{
EVILIA TRISTIYANTI \\ SUARDI \\ SYAMSUL BAHRI DG. PARANI \\ Jurusan Manajemen, Fakultas Ekonomi, Universitas Tadulako \\ Email: eviliatristiyanti@yahoo.com
}

\begin{abstract}
This study aims to determine and analyze the effect of product quality on customer satisfaction using Tupperware products in Palu City. The type of research used is quantitative (showing the relationship between variables). The population of this study is that the general public who have used Tupperware products are not known with certainty. Sampling technique to determine the sample that will be used in this study using the technique of non probability sampling, the purposive sampling with the number of respondents 100 people. Data collection using questionnaire. The analysis method used multiple linear regression analysis. The result of the research showed that (1) There is influence of product quality significantly to customer satisfaction by using Tupperware product in Palu City (2) There is influence of product quality with performance, suitability, endurance, aesthetics and perceived significantly to consumer satisfaction using Tupperware product in Palu City.
\end{abstract}

Keywords: Product quality, Consumer satisfaction.

ABSTRAK
Penelitian ini bertujuan untuk mengetahui dan menganalisa pengaruh kualitas produk terhadap kepuasan konsumen menggunakan produk Tupperware di Kota Palu. Jenis penelitian yang digunakan adalah kuantitatif (menunjukan hubungan antar variabel). Populasi penelitian ini adalah seluruh masyarakat umum yang telah menggunakan produk Tupperware jumlahnya tidak diketahui dengan pasti . Teknik pengambilan sampel untuk menentukan sampel yang akan digunakan dalam penelitian ini menggunakan teknik non probability sampling, yaitu purposive sampling dengan jumlah responden 100 orang. Pengambilan data menggunakan kuesioner. Metode analisis menggunakan analisis regresi linear berganda.Hasil penelitian menunjukkan bahwa (1) terdapat pengaruh Kualitas produk secara signifikan terhadap kepuasan konsumen menggunakan produk Tupperware di Kota Palu (2) terdapat pengaruh kualitas produk dengan kinerja, kesesuaian, daya tahan, estetika dan perceived secara signifikan terhadap kepuasan konsumen menggunakan produk Tupperware di Kota Palu.

Kata Kunci: Kualitas produk, Kepuasan Konsumen.

\section{PENDAHULUAN}

Produk plastik rumah tangga akhir-akhir ini bersaing ketat dan banyak merek baru yang memperlihatkan keunggulan produknya. Salah satu pesaing Tupperware adalah Moorlife yang merupakan produk asal Indonesia yang kualitas dan harganya mampu bersaing dengan Tupperware.

Tabel 1 Perbandingan Tupperware dan Moorlife

\begin{tabular}{|c|l|l|l|}
\hline No. & \multicolumn{1}{|c|}{ Perbandingan } & \multicolumn{1}{c|}{ Moorlife } & \multicolumn{1}{c|}{ Tupperware } \\
\hline 1. & Warna & Lebih terang & Tidak terang \\
\hline 2. & Ketebalan & Lebih tebal & Lebih tipis \\
\hline 3. & Harga & Lebih terjangkau & Lebih mahal \\
\hline 4. & Jenjang karir & Direct selling & Multi level \\
\hline 5. & Buatan & Indonesia & Luar negeri \\
\hline
\end{tabular}

Sumber: www.toko-abee.com 
Tabel di atas dapat disimpulkan kualitas Moorlife lebih unggul dibandingkan Tupperware. Jika dilihat dari segi harga Moorlife lebih terjangkau. Namun, Tupperware lebih tetap banyak diminati oleh masyarakat, sehingga hal ini menjadi masalah dalam penelitian ini karena bertolakbelakang dengan teori yang dikemukakan oleh Ibnu Taimiyah salah satu pakar ekonomi islam, yang menjelaskan sebuah pemahaman yang jelas tentang bagaimana dalam suatu pasar bebas, harga ditentukan oleh kekuatan permintaan dan penawaran, di mana dikatakan jika harga lebih mahal dibandingkan dengan produk yang lain, maka jumlah permintaan akan lebih rendah dibandingkan dengan produk lain.

Satu hal yang unik dan menjadi keunggulan bisnis Tupperware adalah sistem bisnis yang merupakan multi level marketing (MLM). Multi level marketing adalah strategi pemasaran dimana tenaga penjual (sales) tidak hanya mendapatkan kompensasi atas penjualan yang mereka hasilkan, tetapi juga atas hasil penjualan sales lain yang mereka rekrut di mana setiap member mempunyai jenjang karir, penghargaan dan hadiah. Jenjang karir bisnis Tupperware terdiri dari enam tingkat, yaitu: Consultant (C), Team captain (TC), Manager (M), Group Manager (GM), Authorized Group Manager (AGM) dan Distributor (D), di kota Palu terdapat kantor pusat Tupperware di Jl. Basuki Rahmat. Serta ada beberapa manager salah satunya ibu Ira yang beralamat di Jl. Karajalembah, dan Authorized Group Manager (AGM) yang berada di Jl. Tg.Tururuka.

Tupperware juga menjamin produknya tidak bisa dibuang di tempat sampah karena bisa diganti, pemilik Tupperware hanya perlu membawa barang yang lama ataupun yang memiliki kerusakan wajar ke agen-agen terdekat. Karena memiliki kualitas yang baik, Tupperware berani memberikan garansi seumur hidup terhadap kualitas dan kerusakan yang terjadi Konsumen dapat langsung mengembalikan barang yang rusak tersebut ke Tupperware apabila mengalami retak, mengelupas atau sumbing karena penggunaan normal.

Berasarkan uraian yang dikemukakan di atas, maka tujuan penelitian ini adalah:

1. Untuk mengetahui dan menganalisis pengaruh kualitas produk secara signifikan simultan terhadap kepuasan konsumen menggunakan produk Tupperware di Kota Palu.

2. Untuk mengetahui dan menganalisis pengaruh kinerja secara parsial terhadap kepuasan konsumen menggunakan produk Tupperware di Kota Palu.

3. Untuk mengetahui dan menganalisis pengaruh kesesuaian secara parsial terhadap kepuasan konsumen menggunakan produk Tupperware di Kota Palu.

4. Untuk mengetahui dan menganalisis pengaruh daya tahan secara parsial terhadap kepuasan konsumen menggunakan produk Tupperware di Kota Palu.

5. Untuk mengetahui dan menganalisis pengaruh estetika secara parsial terhadap kepuasan konsumen menggunakan produk Tupperware di Kota Palu.

6. Untuk mengetahui dan menganalisis pengaruh perceived secara parsial terhadap kepuasan konsumen menggunakan produk Tupperware di Kota Palu.

\section{KAJIAN LITERATURE}

\section{Pengertian Kualitas Produk}

Menurut Kotler dan Armstrong (2012:283) arti dari kualitas produk adalah kemampuan sebuah produk dalam memperagakan fungsinya, hal itu termasuk keseluruhan durabilitas, reliabilitas, ketepatan, kemudahan pengoperasian dan reparasi produk juga atribut produk lainnya. Menurut Prawirosentono (2004) "Kualitas produk adalah keadaan fisik, fungsi dan sifat produk bersangkutan yang dapat memenuhi selera dan kebutuhan konsumen dengan memuaskan sesuai nilai uang yang telah dikeluarkan".

Goetsch Davis dalam Yamit (2005:8) membuat definisi kualitas yang lebih luas cakupannya, yaitu "kualitas merupakan suatu kondisi dinamis yang berhubungan dengan produk, jasa, manusia, proses, dan lingkungan yang memenuhi atau melebihi harapan". Menurut Boyd (2005) "Apabila perusahaan 
ingin mempertahankan keunggulan kompetitifnya dalam pasar, perusahaan harus mengerti aspek dimensi apa saja yang digunakan oleh konsumen untuk membedakan produk yang dijual perusahaan tersebut dengan produk pesaing".

\section{Dimensi Kualitas Produk}

Dimensi kualitas produk menurut Fandy Tjiptono (2008:25) kualitas produk memiliki beberapa dimensi antara lain:

1. Kinerja (Performance) merupakan karakteristik operasi dan produk inti (core product) yang dibeli. Misalnya kecepatan, kemudahan dan kenyamanan dalam penggunaan.

2. Daya tahan (Durability) berkaitan dengan berapa lama produk tersebut dapat terus digunakan. Dimensi ini mencakup umur teknis maupun umur ekonomis.

3. Kesesuaian dengan spesifikasi (Conformance to Spesification) yaitu sejauh mana karakteristik desain dan operasi memenuhi standar yang telah ditetapkan sebelumnya. Misalnya pengawasan kualitas dan desain, standar karakteristik operasional.

4. Ciri-ciri atau keistimewaan tambahan (Features) yaitu karakteristik sekunder atau pelengkap.

5. Estetika (Esthetica) yaitu daya tarik produk terhadap panca indera. Misal keindahan desain produk, keunikan model produk, dan kombinasi.

6. Keandalan (Realibility) yaitu kemungkinan kecil akan mengalami kerusakan atau gagal pakai. Misalnya pengawasan kualitas dan desain, standar karakteristik operasional.

7. Kualitas yang dipersepsikan (Perceived Quality) merupakan persepsi konsumen terhadap keseluruhan kualitas atau keunggulan suatu produk. Biasanya karena kurangnya pengetahuan pembeli akan atribut atau ciri-ciri produk yang akan dibeli, maka pembeli mempersepsikan kualitasnya dari aspek harga, nama merek, iklan, reputasi perusahaan, maupun negara pembuatnya.

8. Dimensi kemudahan perbaikan (Service ability) meliputi kecepatan, kemudahan, penanganan keluhan yang memuaskan. Pelayanan yang diberikan tidak terbatas hanya sebelum penjualan, tetapi juga selama proses penjualan hingga purna jual yang mencakup pelayanan reparasi dan ketersediaan komponen yang dibutuhkan.

Berdasarkan dimensi yang dikemukakan oleh Fandy Tjiptono terdapat delapan dimensi dari kualitas produk, tetapi dalam penelitian ini peniliti hanya menggunakan enam dimensi dari kualitas produk. Penelitian ini tidak menggunakan dimensi kehandalan dan serviceability karena sudah tercakup dalam dimensi daya tahan dan perceived.

\section{Perilaku Konsumen}

Menurut Schiffman dan Kanuk dalam Sangadji dan Sopiah (2013:7) perilaku konsumen sebagai perilaku yang diperlihatkan konsumen untuk mencari, membeli, menggunakan, mengevaluasi, dan menghabiskan produk dan jasa yang mereka harapkan akan memuaskan kebutuhan mereka. Menurut Hawkins dan Mothersbaugh dalam Tjiptono (2014:50) perilaku konsumen adalah studi mengenai individu, kelompok atau organisasi dan proses-proses yang mereka gunakan untuk menyeleksi, mendapatkan, menggunakan, dan menghentikan pemakaian produk, jasa, pengalaman, atau ide untuk memuaskan kebutuhan, serta dampak proses-proses tersebut terhadap konsumen dan masyarakat.

Menurut Griffin dalam Sangadji dan Sopiah (2013:8) perilaku konsumen adalah semua kegiatan, tindakan, serta proses psikologi yang mendorong tindakan tersebut pada saat sebelum membeli, ketika membeli, menggunakan, menghabiskan produk dan jasa setelah melakukan hal-hal di atas atau kegiatan mengevaluasi.

\section{Kepuasan Konsumen}

Kepuasan atau ketidakpuasan adalah perasaan senang atau kecewa seseorang yang berasal dari perbandingan antara kesannya terhadap kinerja produk, yang riil/actual dengan kinerja produk yang diharapkan. Menurut Zeithaml dan Bitner dalam Sangadji dan Sopiah (2013:180) kepuasan konsumen merupakan "customer's evaluation of a product or service in terms of whether that product or service 
has met their needs and expectation". Konsumen yang merasa puas pada produk/jasa yang dibeli dan digunakannya akan kembali menggunakan jasa/produk yang ditawarkan. Menurut Kotler dalam Sangadji dan Sopiah (2013:181) kepuasan adalah sejauh mana suatu tingkatan produk dipersepsikan sesuai dengan harapan pembeli. Kepuasan konsumen diartikan sebagai suatu keadaan di mana harapan konsumen terhadap suatu produk sesuai dengan kenyataan yang diterima oleh konsumen. Jika produk tersebut jauh dibawah harapan, konsumen akan kecewa. Sebaliknya, jika produk tersebut memenuhi harapan, konsumen akan puas. Harapan konsumen dapat diketahui dari pengalaman mereka sendiri saat menggunakan produk tersebut, informasi dari orang lain, dan informasi yang diperoleh dari iklan atau promosi lain.

Kepuasan konsumen diukur dengan seberapa besar harapan konsumen tentang produk dan pelayanan sesuai dengan kinerja produk dan pelayanan yang aktual. Menurut Kotler dalam Sangadji dan Sopiah (2013:181) kepuasan konsumen adalah perasaan senang atau kecewa yang muncul setelah membandingkan persepsi atau kesan dengan kinerja suatu produk dan harapan-harapannya. Setelah mengonsumsi produk, konsumen akan merasakan kepuasan atau kekecewaan. Kepuasan akan mendorong konsumen untuk membeli ulang produk. Sebaliknya, jika kecewa, konsumen tidak akan membeli produk yang sama lagi di kemudian hari. Kepuasan konsumen merupakan evaluasi purnabeli dimana alternatif yang dipilih sekurang-kurangnya sama atau melampaui harapan konsumen.

Beberapa dimensi kepuasan konsumen menurut Irawan (2008:9) adalah sebagai berikut:

a. Kepuasan konsumen secara menyeluruh. Para konsumen yang membeli produk Tupperware akan merasa puas setelah menggunakan produk tersebut.

b. Merekomendasikan kepada orang lain. Konsumen yang merasa puas akan memberi informasi kepada kerabat dan temannya, jika produk Tupperware itu banyak diminati oleh ibu-ibu rumah tangga, anak-anak muda baik yang wanita maupun laki-laki.

c. Akan melakukan pembelian kembali. Konsumen puas dengan produk Tupperware, konsumen pasti akan membeli dan menggunakan kembali produk tersebut.

Berdasarkan pengertian-pengertian di atas, dapat disimpulkan bahwa kepuasan konsumen adalah suatu tingkatan produk yang sesuai dengan keinginan konsumen sehingga konsumen akan melakukan pembelian ulang pada produk yang sama tersebut. Akan tetapi dalam penelitian ini, peneliti hanya menggunakan dimensi yang sesuai dengan penelitian yaitu kepuasan konsumen secara menyeluruh.

\section{Kerangka Pemikiran}

KUALITAS PRODUK

Fandy Tjiptono (2008:25)

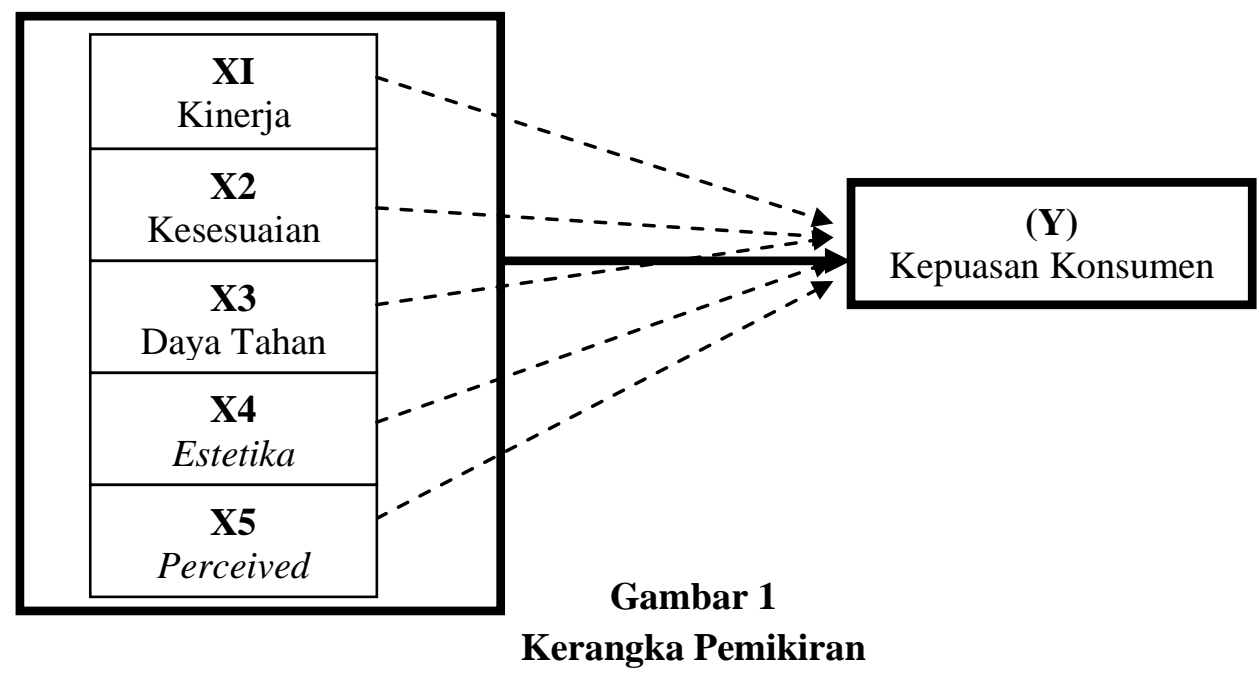




\section{Hipotesis}

Teori dan kerangka berpikir diatas dapat disusun beberapa hipotesis sebagai berikut:

1. Kualitas produk berpengaruh secara simultan terhadap kepuasan konsumen menggunakan produk Tupperware di Kota Palu.

2. Variabel kinerja berpengaruh secara parsial terhadap kepuasan konsumen menggunakan produk Tupperware di Kota Palu.

3. Variabel kesesuaian berpengaruh secara parsial terhadap kepuasan konsumen menggunakan produk Tupperware di Kota Palu.

4. Variabel daya tahan berpengaruh secara parsial terhadap kepuasan konsumen menggunakan produk Tupperware di Kota Palu.

5. Variabel estetika berpengaruh secara parsial terhadap kepuasan konsumen menggunakan produk Tupperware di Kota Palu.

6. Variabel perceived berpengaruh secara parsial terhadap kepuasan konsumen menggunakan produk Tupperware di Kota Palu.

\section{METODE PENELITIAN}

Penelitian ini termasuk ke dalam jenis kausalitas karena penelitian ini bersifat menunjukan hubungan antar dua variabel atau lebih, atau bagaimana satu variabel mempengaruhi variabel lainnya Travers dalam Umar (2003:87). Peneliti melakukan survei untuk mengambil data di lapangan. Menurut Sugiyono (2014:80) penelitian survei adalah metode penelitian yang digunakan untuk mendapatkan data yang terjadi pada masa lampau, atau saat ini, tentang keyakinan, pendapat, karekteristik, perilaku, hubungan variabel untuk menguji beberapa hipotesis dari sampel yang diambil dari populasi tertentu. Penelitian ini menggunakan teknik pengambilan dan pengumpulan data yang dilakukan dengan cara kuesioner dan wawancara. Populasi penelitian ini adalah seluruh masyarakat umum yang telah menggunakan produk Tupperware jumlahnya tidak diketahui dengan pasti.

Teknik pengambilan sampel untuk menentukan sampel yang akan digunakan dalam penelitian ini menggunakan Teknik non probability sampling, yaitu purposive sampling. Dikarenakan jumlah populasinya tidak diketahui secara pasti maka untuk menentukan besarnya sampel yaitu dengan menggunakan rumus Unknown Populations Frendy dalam Ekasari (2014:98)

$$
\mathrm{n}=\frac{\mathrm{Z}^{2}}{4 \mu^{2}}
$$

Keterangan:

$\mathrm{n}=$ ukuran sampel

$\mathrm{Z}=$ tingkat keyakinan sampel yang dibutuhkan dalam penelitian, pada $\alpha=5 \%$ (derajat keyakinan ditentukan 95\%) maka $\mathrm{Z}=1,96$

$\mu=$ margin of error, tingkat kesalahan yang dapat ditolerir (ditentukan 10\%)

Menggunakan rumus diatas, maka diperoleh perhitungan sebagai berikut:

$$
\begin{aligned}
& \mathrm{n}=\frac{1,96^{2}}{4(0,1)^{2}} \\
& \mathrm{n}=96,4 \approx 100 \text { responden }
\end{aligned}
$$

Penelitian ini menggunakan aplikasi software SPSS (Statistical Program for Social Scane) versi 16.0 yang dipakai untuk menganalisis pengaruh secara simultan dan pengaruh secara parsial variabel Independen terhadap dependen. Mengukur dan menganalisis besarnya hubungan kualitas dan harga produk terhadap kepuasan konsumen menggunakan produk Tupperware di Kota Palu, menggunakan alat analisis statistic parametric regresi linear berganda (Multiple Regression Analisis). Menurut 
Sugiyono (2014:277) bahwa model umum bentuk persamaan alat analisis statistic parametric regresi linear berganda dapat digambarkan sebagai berikut persamaan struktural dalam model sebagai berikut:

$\mathbf{Y}=\mathbf{a}+\mathbf{b}_{1} \mathbf{X}_{1}+\mathbf{b}_{2} \mathbf{X}_{2}+e$

Dimana:

$\mathrm{Y}=$ Kepuasan Konsumen

$\mathrm{X}_{1}=$ Kualitas produk

A $=$ Konstanta

$b_{1-} b_{2}=$ Koefisien Regresi

\section{HASIL DAN PEMBAHASAN}

Analisis Regresi Berganda

Tabel 3

Hasil Analisis Regresi Linear Berganda

\begin{tabular}{|c|c|c|c|c|c|}
\hline \multicolumn{6}{|c|}{ Dependen Variabel $Y=$ Kepuasan Konsumen } \\
\hline \multirow{2}{*}{$\begin{array}{c}\text { Variabel Independen } \\
\text { (Dimensi Kualitas } \\
\text { Produk) }\end{array}$} & \multicolumn{2}{|c|}{$\begin{array}{l}\text { Unstandardized } \\
\text { Coefficients }\end{array}$} & \multirow{2}{*}{$\begin{array}{c}\begin{array}{c}\text { Standardized } \\
\text { Coefficients }\end{array} \\
\text { Beta }\end{array}$} & \multirow[t]{2}{*}{$\mathbf{T}$} & \multirow[t]{2}{*}{ Sig } \\
\hline & $\mathbf{B}$ & $\begin{array}{c}\text { Standar } \\
\text { Error }\end{array}$ & & & \\
\hline $\mathrm{C}=$ Constanta & -.302 & .351 & & -.860 & .392 \\
\hline kinerja. $\left(\mathrm{X}_{1}\right)$ & .538 & .077 & .574 & 6.977 & .000 \\
\hline kesesuaian. $\left(\mathrm{X}_{2}\right)$ & .115 & .051 & .108 & 2.250 & .027 \\
\hline daya tahan. $\left(\mathrm{X}_{3}\right)$ & .252 & .066 & .313 & 3.835 & .000 \\
\hline estetika. $\left(\mathrm{X}_{4}\right)$ & .114 & .044 & .125 & 2.562 & .012 \\
\hline perceived. $\left(\mathrm{X}_{5}\right)$ & .127 & .046 & .133 & 2.739 & .007 \\
\hline $\begin{array}{ll}\text { Multiple } R & =.88 \\
\text { R Square }\left(R^{2}\right) & =.78\end{array}$ & & ig.F & & & \\
\hline
\end{tabular}

Hasil tersebut apabila ditulis dalam bentuk persamaan regresinya adalah sebagai berikut:

$Y=-0,302+0,538 X 1+0,115 X 2+0,252 X 3+0,114 X 4+0,127 X 5$

\section{Pembahasan}

\section{Pengujian Hipotesis Pertama (Uji F)}

Hasil pengujian yang telah dilakukan seperti yang terlihat pada Tabel.3 di atas maka dapat angka signifikansi sebesar 0,000 . Angka $0,000<0,05$ oleh karena itu, hipotesis diterima, hal ini berarti terdapat pengaruh secara simultan variabel kualitas produk yang terdiri dari kinerja, kesesuaian, daya tahan, estetika dan perceived terhadap kepuasan konsumen produk Tupperware di Kota Palu.

\section{Pengujian Hipotesis (Uji t)}

Variabel Kinerja $\left(\mathbf{X}_{1}\right)$

Berdasarkan Tabel.3, hasil pengujian dengan SPSS diperoleh angka signifikansi sebesar 0,000. Angka 0,000 > 0,05 oleh karena itu, hipotesis diterima. Hal ini berarti terdapat pengaruh variabel kualitas produk yaitu kinerja terhadap kepuasan konsumen prosuk Tupperware di Kota Palu. 


\section{Variabel Kesesuaian $\left(\mathbf{X}_{2}\right)$}

Berdasarkan Tabel.3, hasil pengujian dengan SPSS angka signifikansi sebesar 0,027. Angka $0,027<0,05$ oleh karena itu, hipotsesis diterima. Hal ini berarti terdapat pengaruh variabel kinerjayaitu kesesuaian terhadap kepuasan konsumen produk Tupperware di Kota Palu.

\section{Variabel Daya Tahan $\left(\mathbf{X}_{3}\right)$}

Berdasarkan Tabel.3, hasil pengujian dengan SPSS diperoleh angka signifikansi sebesar 0,000. Angka $0,000<0,05$ oleh karena itu, hipotesis diterima. Hal ini berarti terdapat pengaruh variabel kualitas produk yaitu daya tahan terhadap kepuasan konsumen produk Tupperware di Kota Palu.

\section{Variabel Estetika $\left(\mathbf{X}_{4}\right)$}

Berdasarkan Tabel.3, hasil pengujian dengan SPSS diperoleh angka signifikansi sebesar 0,012. Angka $0,012<0,05$ oleh karena itu, hipotesis ditolak. Hal ini berarti tidak terdapat pengaruh variabel kualitas produk yaitu estetika terhadap kepuasan konsumen produk Tupperware di Kota Palu.

\section{Variabel Perceived $\left(\mathrm{X}_{5}\right)$}

Berdasarkan Tabel.3, hasil pengujian dengan SPSS diperoleh angka signifikansi sebesar 0,007. Angka $0,007<0,05$ oleh karena itu, hipotesis ditolak. Hal ini berarti tidak terdapat pengaruh variabel kualitas produk yaitu perceived terhadap kepuasan konsumen produk Tupperware di Kota Palu.

\section{Koefisien Determinasi $\left(\mathbf{R}^{2}\right)$}

Tabel 4 Koefisien determinasi

\begin{tabular}{|l|r|r|r|r|}
\hline Model & $\mathrm{R}$ & $\mathrm{R}$ Square & \multicolumn{1}{|c|}{$\begin{array}{c}\text { Adjusted R } \\
\text { Square }\end{array}$} & $\begin{array}{l}\text { Std. Error of the } \\
\text { Estimate }\end{array}$ \\
\hline 1 & $.889^{\mathrm{a}}$ & .789 & .778 & .24322 \\
\hline
\end{tabular}

a. Predictors: (Constant), perceived, DayaTahan, kesesuaian, estetika, kinerja

Koefisien determinasi yang diperoleh sebesar 0,789. Hal ini berarti 78,9\% kepuasan konsumen dapat dijelaskan oleh variabel kualitas produk yaitu kinerja, kesesuaian, daya tahan, estetika, dan perceived, sedangkan sisanya yaitu 99,2\% kepuasan konsumen dipengaruhi oleh variabel-variabel lainnya yang tidak diteliti dalam penelitian ini.

\section{KESIMPULAN DAN SARAN}

\section{Kesimpulan}

1. Terdapat pengaruh secara simultan kualitas produk terhadap kepuasan konsumen menggunakan produk Tupperware di Kota Palu. Angka signifikansi sebesar 0,000<0,05.

2. Terdapat pengaruh secara parsial variabel kinerja terhadap kepuasan konsumen menggunakan produk Tupperware di Kota Palu. Angka signifikansi sebesar 0,000 < 0,05.

3. Terdapat pengaruh secara parsial variabel kesesuaian terhadap kepuasan konsumen menggunakan produk Tupperware di Kota Palu. Angka signifikansi sebesar 0,027 <0,05.

4. Terdapat pengaruh secara parsial variabel daya tahan terhadap kepuasan konsumen menggunakan produk Tupperware di Kota Palu. Angka signifikansi sebesar $0,000<0,05$.

5. Terdapat pengaruh secara parsial variabel estetika terhadap kepuasan konsumen menggunakan produk Tupperware di Kota Palu. Angka signifikansi sebesar 0,012<0,05.

6. Terdapat pengaruh secara parsial variabel perceived terhadap kepuasan konsumen menggunakan produk Tupperware di Kota Palu. Angka signifikansi sebesar 0,007 <0,05. 
Tristiyanti, E.

\section{Saran}

1. Bagi Perusahaan

Peneliti menyarankan agar PT.Tupperware meningkatkan kualitas produk dengan selalu berinovasi. Tak lupa PT.Tupperware harus lebih meningkatkan kinerja, kesesuaian, daya tahan, estetika dan perceived yang lebih baik lagi agar konsumen akan tetap merasa puas dalam menggunakan produk Tupperware dan tetap menjadi pilihan konsumen dalam menggunakan wadah plastik berkualitas.

2. Bagi Peneliti Selanjutnya

Bagi peneliti selanjutnya yang ingin meneliti atau melanjutkan penelitian ini, disarankan untuk meneruskan atau mengembangkan penelitian ini dengan mencari faktor lain yang dapat mempengaruhi kepuasan konsumen. Selain menyebarkan kuesioner, penelitian selanjutnya sebaiknya disertai dengan wawancara sehingga data yang diperoleh lebih lengkap dan dapat mengurangi data yang bersifat subyektif.

\section{REFERENSI}

Boyd, Harper, W. Ovrille, C. Larreche, Jean-Claude, Mullin, John. W. (2005). Manajemen

Pemasaran. Edisi Kedua. Jakarta: Erlangga.

Ekasari, Novita. (2014). Pengaruh Promosi Berbasis Social Media terhadap keputusan pembelian Produk Jasa Pembiayaan Kendaraan PT. BFI Finance Jambi. Jurnal Volume 16, Nomor 2, Hal. 81-102 (ISSN: 0852-8349). Universitas Jambi.

Irawan, Handi. (2008). Membedah Strategi Kepuasan Pelanggan . Cetaka Pertama. Jakarta: Pradnya Paramitha, h. 45. Kelompok Gramedia.

Kotler, Philip \& Kevin Lane Keller, (2008). Manajemen Pemasaran, Edisi Ketiga Belas Jilid I, Terjemahan Bob Sabran. Jakarta: Erlangga.

Kotler Philip \& Gary Amstrong . (2012). Principles of marketing, Global Edition, 14 Edition. Pearson Education. New Jersey: Prentice Hall.

Prawirosentono, Suyadi. (2004). Manajemen Mutu Terpadu. Jakarta: Bumi Aksara.

Sangadji, Etta Mamang \& Sopiah. (2013). Perilaku Konsumen. Yogyakarta: CV. Andi offset.

Sugiyono. (2014). Metodologi Penelitian Manajemen: Pendekatan Kuantitatif, Kualitatif, Kombinasi, Penelitian Tindakan dan Penelitian Evaluasi. Cetakan Ke-3, Bandung: Alfabeta.

Tjiptono, Fandy. (2008). Service Management, Mewujudkan Layanan prima.Yogyakarta: Andi Offset.

Tjiptono, Fandy. (2014). Pemasaran Jasa: Prinsip, Penerapan, dan Penelitian. Edisi Pertama. Yogyakarta: Andi.

Umar, Husein . (2003). Metodologi Penelitian: Aplikasi dalam Pemasaran. Jakarta: PT. Gramedia Pustaka Utama.

Yamit, Zulian. (2005). Manajemen Kualitas Produk dan Jasa. Edisi Keempat. Jakarta: Ekonisia. www.toko-abee.com (diakses 11 Februari 20017) 